\title{
Clinical Validation of Impaired Spirituality in Patients with Chronic Renal Disease ${ }^{1}$
}

\author{
Erika de Cássia Lopes Chaves² \\ Emilia Campos de Carvalho ${ }^{3}$ \\ Fabio de Souza Terra ${ }^{4}$ \\ Luiz de Souza ${ }^{5}$
}

This study aimed to identify and validate the defining characteristics of the nursing diagnosis Impaired spirituality. The methodological framework proposed by Fehring for the clinical validation of nursing diagnosis was used. The investigation was carried out in a dialysis clinic and had as participants 120 patients with chronic renal disease. Data were collected by two expert nurses, through interviews. The prevalence of the nursing diagnosis Impaired spirituality in the sample was $27.5 \%$. It was found that the most frequent defining characteristics were Expresses behavioral changes: rage, Inability to express creativity, Questions suffering and Expresses alienation. The clinical validation of Impaired spirituality contributed to refine this diagnosis. Its identification in patients with chronic renal disease undergoing dialysis treatment can offer alternatives for a safer and more effective intervention, aiming at the satisfaction of the spiritual needs of these patients.

Descriptors: Nursing Diagnosis; Spirituality; Renal Insufficiency, Chronic; Renal Dialysis; Validation Studies.

\footnotetext{
${ }^{1}$ Paper extracted from Doctoral Dissertation "Revisão do diagnóstico de enfermagem Angústia Espiritual", presented to Escola de Enfermagem de Ribeirão Preto, Universidade de São Paulo, SP, Brazil.

2 RN, Ph.D. in Nursing, Faculty, Departamento de Enfermagem, Universidade Federal de Alfenas, MG, Brazil. E-mail: echaves@unifal-mg.edu.br.

${ }^{3}$ RN, Full Professor, Escola de Enfermagem de Ribeirão Preto, Universidade de São Paulo, WHO Collaborating Centre for Nursing Research Development, SP, Brazil. E-mail: ecdcava@usp.br.

${ }^{4}$ RN, Doctoral Student, Fundamental Nursing Graduate Program, Escola de Enfermagem de Ribeirão Preto, Universidade de São Paulo, WHO Collaborating Centre for Nursing Research Development, SP, Brazil. E-mail: fabioterra@usp.br.

${ }^{5}$ Mathematician, Faculty, Faculdade de Medicina, Universidade de São Paulo, Brazil. E-mail: Idsouza@fmrp.usp.br.
}

Corresponding Author:

Emilia Campos de Carvalho

Universidade de São Paulo. Escola de Enfermagem de Ribeirão Preto

Av. dos Bandeirantes, 3900.

Bairro Monte Alegre

CEP: 14040-902 Ribeirão Preto, SP, Brasil

E-mail: ecdcava@usp.br 


\title{
Validação clínica de espiritualidade prejudicada em pacientes com doença renal crônica
}

Este estudo teve por objetivo identificar e validar as características definidoras do diagnóstico de enfermagem espiritualidade prejudicada. Foi utilizado o referencial metodológico proposto por Fehring para validação clínica de diagnóstico de enfermagem. A investigação decorreu em uma clínica de hemodiálise e contou com a participação de 120 pacientes com doença renal crônica. Os dados foram coletados por dois enfermeiros peritos, por meio de entrevistas. A prevalência do diagnóstico de enfermagem espiritualidade prejudicada, na amostra, foi de $27,5 \%$. Constatou-se que as características definidoras mais frequentes foram: expressa alteração de comportamento: raiva, é incapaz de expressar criatividade, questiona sofrimento e expressa alienação. A validação clínica de espiritualidade prejudicada contribuiu para o refinamento desse diagnóstico e sua identificação, junto a pacientes com doença renal crônica em hemodiálise, pode oferecer caminhos para intervenção mais segura e eficaz, visando a satisfação das necessidades espirituais desses pacientes.

Descritores: Diagnóstico de Enfermagem; Espiritualidade; Insuficiência Renal Crônica; Diálise Renal; Estudos de Validação.

\section{Validación clínica de espiritualidad perjudicada en pacientes con enfermedad renal crónica}

\begin{abstract}
Este estudio tuvo por objetivo identificar y validar las características definidoras del diagnóstico de enfermería espiritualidad perjudicada. Fue utilizado el marco metodológico propuesto por Fehring para validación clínica del diagnóstico de enfermería. La investigación se realizó en una clínica de hemodiálisis y contó con la participación de 120 pacientes con enfermedad renal crónica. Los datos fueron recolectados por dos enfermeros especialistas, por medio de entrevistas. La prevalencia del diagnóstico de enfermería espiritualidad perjudicada, en la muestra, fue de $27,5 \%$. Se constató que las características definidoras más frecuentes fueron: expresa alteración de comportamiento: rabia, es incapaz de expresar creatividad, cuestiona sufrimiento y expresa alienación. La validación clínica de espiritualidad perjudicada contribuyó para el refinamiento de ese diagnóstico y su identificación, en pacientes con enfermedad renal crónica en hemodiálisis; éste puede ofrecer alternativas para una intervención más segura y eficaz, con el objetivo de satisfacer las necesidades espirituales de esos pacientes.
\end{abstract}

Descriptores: Diagnóstico de Enfermería; Espiritualidad; Insuficiencia Renal Crónica; Diálisis Renal; Estudios de Validación.

\section{Introduction}

Patients with chronic illnesses are constantly faced with situations whose complexity goes beyond the clinical aspects of the disease, deals with the suffering provoked by difficult moments, of great rejection, guilt and struggles, in the daily attempt to live in harmony with their health condition. Chronic renal disease (CRD) specifically imposes a series of changes and new life perspectives on people, including continuous medication use, coping with dependence on others and on machines to adapt to the new reality and in most cases, financial dependence(1). $^{(1)}$.

Living with the disease and the painful treatment generates existential conflicts that can provoke spiritual anguish which, in turn, aggravates the physical and emotional symptoms and the ability to cope with the disease(2).

The North American Nursing Diagnosis Association - International (NANDA-I) acknowledged the spiritual 
anguish response, originally spiritual distress, as a pertinent nursing diagnosis. This diagnosis is rarely identified in practice though, due to its complexity, nurses' difficulty to identify its evidence, as well as to gaps in this knowledge aspect and, often, lack of interest with regard to the spirituality phenomenon ${ }^{(3)}$.

An integrative review ${ }^{(4)}$ on spiritual anguish was carried out to identify the concept proposed in literature with regard to the phenomenon and the clinical indicators that evidence its presence. This resulted in a new proposal for the diagnosis, later submitted to content validation by experts(5). According to these authors ${ }^{(4-5)}$, the diagnosis title that best describes the harm suffered in the spiritual dimension is impaired spirituality. This proposal is supported by the acknowledgement that this diagnosis title will offer the possibility of expanding the network of diagnoses to describe individuals' responses to changes in this human dimension and is also based on the understanding of spirituality as a continuum. The following defining characteristics were identified and validated(5): expresses alienation, questions suffering, expresses behavioral alteration: anger, incapable of expressing creativity, expresses lack of meaning/purpose in life, expresses lack of serenity, expresses behavioral alteration: crying, expresses lack of courage, expresses lack of hope, expresses feeling of guilt, refuses integration with significant others, feels abandoned, feeling of grief, requests spiritual assistance, incapable of experiencing transcendence, presents disorder or concern with the system of beliefs and/or God, expresses anger with God, expresses lack of love, expresses lack of hope, feeling of temporality and does not take interest in nature. It should be highlighted that, among these defining characteristics, some are included in NANDA ${ }^{(6)}$, while others were modified or grouped so as to better represent the concepts found in literature. This author ${ }^{(5)}$ added three characteristics that were not part of those proposed in the NANDA Taxonomy II: feeling of temporality, expresses behavioral alteration: crying and feeling of grief.

To formulate diagnoses related to spirituality, nurses need to face the challenge to interpret patients' spiritual behavior and judge what diagnosis will best represent the defining characteristics displayed. These diagnoses do not only have some characteristics in common though, but are also marked by a high degree of abstraction, with little consensus in literature about a definition. Therefore, the theoretical-clinical knowledge that sustains them is very important, as well as their confirmation in the clinical context through a validation process.
The validation process of a nursing diagnosis is similar to the procedures used to validate measurement instruments, in which validity refers to the extent to which a measurement instrument measures exactly what it should measure. Validating a nursing diagnosis means determining the extent to which it represents the patient's response to a situation, refining the set of clinical indicators through which it can be described. According to Fehring(7), a diagnosis is only valid when it is evidence based and capable of withstanding nursing professionals' criticism. Its characteristics are valid when they truly occur and are identified in clinical situations.

In that context, this research aims to identify and clinically validate the defining characteristics proposed for the nursing diagnosis impaired spirituality.

\section{Method}

In this descriptive and observational study, 120 adult patients with chronic renal diseases were evaluated who were undergoing hemodialysis treatment. It was carried out in the first semester of 2008 at a medium-sized general philanthropic hospital in Minas Gerais (Brazil).

In compliance with Resolution 196/96 on research involving human beings, approval for the research project was obtained from the Internal Review Board at the University of São Paulo at Ribeirão Preto College of Nursing (Protocol No 0810/2007). Also, in compliance with ethical requirements, formal consent with the project was obtained from the institution that administers the renal therapy clinic.

The following criteria were established for inclusion or exclusion: being a CRD patient and undergoing hemodialysis (HD), 18 years of age or older, independently of gender, being oriented in time, space and person, being able to verbally express oneself and formally consenting to participate in the research by signing the free and informed consent term (FICT).

As the diagnosis under analysis refers to a cognitive response, directed at people's spirituality, the researchers decided to obtain clinical information directly from the patient. The methodological reference framework was based on Fehring's clinical diagnostic validation model(7).

Data were collected through interviews. A script was used to evaluate the nursing diagnosis impaired spirituality's defining characteristics, which were presented with their respective definitions, aimed at identifying the presence or absence of each of these characteristics. To facilitate statistical treatment, one 
single question was elaborated with dichotomous answers (yes/no) for each diagnostic characteristic, in which the affirmative alternative was interpreted as presence of the characteristic. This instrument was submitted to a refining process, with a view to assessing its clarity, objectiveness and range with regard to what it was aimed to identify.

Data were collected simultaneously but individually by two nurse experts, respecting the recommendations of the adopted model(7). Each nurse's judgment was written down on a separate form so as to observe agreement in a later stage.

Next, the presence of the study diagnosis was verified in the study subjects, asking the following direct question to the patient: do you feel that your spirituality is impaired? Later, the nurses' assessment was compared with the patient's answer.

Asking the patient direct questions is based on the fact that no gold standard reference was found in literature to assess spirituality, considering that there is no consensus either about the concept attributed to this phenomenon, which has been described as a personal experience $^{(8)}$ and, as such, the patient's opinion about the presence of harm in this dimension became the reference criterion to identify the nursing diagnosis impaired spirituality. Moreover, some of the indicators for the diagnosis under study describe subjective and overlapping manifestations and which are, hence, difficult to analyze. In this sense, the best reference is the patient's own confirmation(9).

Nurses' diagnostic reasoning was not considered the main or reference criterion due to the lack of definitive resources to verify this skill and, also, as observed, because this diagnosis involves a cognitive response, making its evaluation more difficult.

Statistical Package for the Social Sciences (SPSS) software, version 15, was used for data analysis. Data were described and summarized through descriptive statistics. Agreement analysis - Kappa was used to determine agreement between the patient's opinion on the presence of the diagnosis and the nurse researcher's judgment, as no disagreement was found between the nurses' assessments. Kappa agreement levels were interpreted in accordance with specialized literature, that is: Kappa below 0: null; from 0 to 0.20 : poor; from 0.21 to 0.40 : fair; from 0.41 to 0.60 : moderate; 0.61 to 0.80 : substantial and from 0.81 to 1.00 : perfect agreement $^{(10)}$.

To analyze the extent to which each characteristic indicates the diagnosis, the frequency of the defining characteristics in the study participants was observed. Among those subjects with impaired spirituality, defining characteristics with frequency levels of $80 \%$ or more were classified as primary characteristics, frequencies between 79 and $51 \%$ as secondary and frequencies of $50 \%$ or less as characteristics of little relevance. Characteristics with frequency levels of $50 \%$ or less will be considered not validated in this research. Also, drawing a parallel with the diagnostic content validation model used(7), the diagnosis' total score was calculated, which corresponds to the sum of all defining characteristics' mean scores, except for those items scoring 0.50 or less, divided by the total number of validated characteristics.

\section{Results}

\section{Subject characteristics}

Most of the study participants $(n=120)$ were female $(n=61)$, married $(n=63)$ and Catholic $(n=95)$. With regard to education level, unfinished primary education prevailed $(n=69)$. Few participants finished secondary or higher education, which confirms subjects' low education level (Table 1 ).

When asked about their religious practice, 87 patients answered that they participate in religious activities related to their belief and that they consider religion something very important in life.

Table 1 - Distribution of study participants according to education level, civil status and religious beliefs. Ribeirão Preto, $2008(\mathrm{~N}=120)$

\begin{tabular}{lcc}
\multicolumn{1}{c}{ Study variables } & Frequency & $\%$ \\
\hline Education & 12 & 10 \\
Has never gone to school & 69 & 57.5 \\
Unfinished primary & 9 & 7.5 \\
Finished primary & 6 & 5 \\
Unfinished secondary & 12 & 10 \\
Unfinished secondary & 4 & 3.3 \\
Unfinished higher & 7 & 5.8 \\
Unfinished higher & 1 & 0.8 \\
Finished postgraduate program & & \\
Religious belief & 95 & 79.2 \\
Catholic & 15 & 12.5 \\
Evangelic & 3 & 2.5 \\
Unspecified religion but believes in God & 2 & 1.7 \\
Atheist & 2 & 1.7 \\
Spiritist & 3 & 2.5 \\
Other & & \\
Importance of religion in life & 20 & 10 \\
Very important & 62 & 51.7 \\
Important & 23.3 \\
Somewhat important & & \\
Not important & & \\
\hline
\end{tabular}


With respect to the time passed since they discovered the disease and time under $\mathrm{HD}$, on the average, seven years and six months had passed since they discovered the disease and four years and eight months of hemodialysis treatment. Some patients were in treatment for 18 years and knew about their disease for 38 years, while others had discovered it only two months ago and had been in treatment for one month.

\section{Identification of nursing diagnosis impaired spirituality}

Participants were 120 patients with CRD, 33 of whom presented the nursing diagnosis impaired spirituality.

The diagnosis was simultaneously determined by two nurses, without any disagreements; the agreement level between the patient's own opinion and the nurse's assessment with regard to the presence of the diagnosis was found "perfect" $(K=0.92)$. Thus, it can be deducted that the nurse's judgment about the presence of the diagnosis was ratified by the patient's assessment.

The 21 defining characteristics proposed for the nursing diagnosis impaired spirituality were observed in the study population with different frequency levels. The most prevailing characteristics were: is incapable of expressing creativity (68.3\%) and requests spiritual assistance $(50 \%)$. The remainder was present in less than $45 \%$ of the subjects.

It should be highlighted that the frequency of the nursing diagnosis impaired spirituality was $27.5 \%$ $(n=33)$. Only the defining characteristic is incapable of expressing creativity was present in more than 50\% of participants who affirmed that they did not present impaired spirituality.

\section{Frequency and validation of defining characteristics in impaired spirituality patients}

Among the 21 defining characteristics investigated by the impaired spirituality evaluation script, 15 were identified in most patients who presented the nursing diagnosis impaired spirituality, with frequencies between 15.2 and $48.5 \%$ for the remaining six (Table 2 ).

Four characteristics scored higher than $80 \%$ and were classified as the diagnosis' primary characteristics: expresses behavioral alteration: anger, is incapable of expressing creativity, questions suffering and expresses alienation. Eleven other characteristics were considered secondary as their frequencies ranged between 79 and $51 \%$. Thus, 15 characteristics were considered valid for the diagnosis under analysis in the study group.
Table 2 - Simple frequency (f) and percentage (\%) distribution of defining characteristics in CRD patients undergoing HD who presented the nursing diagnosis impaired spirituality. Ribeirão Preto, $2008(n=33)$

\begin{tabular}{|c|c|c|}
\hline \multirow{2}{*}{ Defining characteristics } & \multicolumn{2}{|c|}{ Frequency } \\
\hline & f & $\%$ \\
\hline Expresses behavioral alteration: anger & 29 & 87.9 \\
\hline Incapable of expressing creativity & 29 & 87.9 \\
\hline Expresses alienation & 28 & 84.8 \\
\hline Questions suffering & 27 & 81.8 \\
\hline Feels abandoned & 25 & 75.8 \\
\hline Expresses lack of serenity & 25 & 75.8 \\
\hline Feeling of temporality & 24 & 72.7 \\
\hline Expresses lack of hope & 22 & 66.7 \\
\hline Expresses behavioral alteration: crying & 22 & 66.7 \\
\hline Expresses feeling of guilt & 21 & 63.6 \\
\hline Refuses integration with significant others & 21 & 63.6 \\
\hline Expresses lack of meaning/purpose in life & 19 & 57.6 \\
\hline Expresses lack of courage & 19 & 57.6 \\
\hline Requests spiritual assistance & 18 & 54.5 \\
\hline Feeling of grief & 17 & 51.5 \\
\hline Expresses lack of love & 16 & 48.5 \\
\hline Expresses despair & 16 & 48.5 \\
\hline Does not take interest in nature & 15 & 45.5 \\
\hline $\begin{array}{l}\text { Presents disorder or concern with the } \\
\text { system of beliefs and/or God }\end{array}$ & 9 & 27.3 \\
\hline Expresses anger with God & 7 & 21.2 \\
\hline Incapable of experiencing transcendence & 5 & 15.2 \\
\hline
\end{tabular}

Six characteristics obtained frequencies below $50 \%$ and were considered of little relevance for the nursing diagnosis impaired spirituality, which were: expresses lack of love (48.5\%), expresses despair (48.5\%), does not take interest in nature (45.5\%), presents disorder or concern with the system of beliefs $(27.3 \%)$, expresses anger with God (21.2\%) and is incapable of experiencing transcendence (15.2\%) (Table 2).

Of these, the defining characteristics expresses anger with God, expresses lack of love and does not take interest in nature are included in NANDA(6). The characteristics presents disorder or concern with the system of beliefs and/or God, is incapable of experiencing transcendence and expresses despair, adopted in this research, were modified or grouped for the sake of a better representation of the concepts found in literature, in a preceding step of the validation ${ }^{(5)}$. The remaining defining characteristics analyzed were considered validated. 
The total score of the diagnosis validation was calculated $^{(7)}$, based on the frequencies of the defining characteristics that were considered validated in the group of CRD patients with impaired spirituality. The result found was 0.70 , based on which the diagnosis can be considered validated(7).

\section{Discussion}

In nursing, Brazilian research has called attention to different physical, social and emotional problems faced by patients with chronic renal disease undergoing $\mathrm{HD}^{(1,11-12)}$. Spiritual issues, however, have been addressed little. This research found that $27.5 \%$ of patients under analysis have the nursing diagnosis impaired spirituality. These results are relevant because this patient group presents an important conflict in the spiritual dimension, which can compromise their ability to deal with the renal disease, interfering in positive treatment outcomes and also aggravating physical and emotional symptoms ${ }^{(2)}$.

Literature $^{(13)}$ presents "anger" as a "minor" defining characteristic of the diagnosis under analysis, that is, it may be present, but not necessarily, when a person presents the diagnosis. In this research, the characteristic expresses behavioral alteration: anger was identified as one of the most frequent clinical indicators, and was therefore classified as a "primary characteristic" of impaired spirituality.

Another defining characteristic that was considered important was expresses alienation, which supported the findings of a systematic literature review ${ }^{(14)}$, covering research carried out between 1966 and 2006, about the spiritual perspective of adult patients with terminal diseases. Based on a sample of 11 articles, which together represented data of 217 adults, the feeling of alienation was highlighted as an important aspect of spiritual suffering. The "feeling of a spiritual void" is described as a secondary defining characteristic(13).

The characteristic questions suffering also showed to be one of the primary characteristics for the diagnosis under analysis. In another study(2) aimed at identifying the spiritual needs of cancer patients, it was observed that these patients faced difficulties to interpret the meaning of the disease, decreasing their capacity to control what was happening and feeding their suffering.

The characteristic is incapable of expressing creativity was also very frequent among patients with impaired spirituality. NANDA has proposed this characteristic for the spiritual anguish diagnosis since 2002, but it had not been submitted to clinical validation yet. This characteristic was also frequent among study participants who did not present impaired spirituality though; hence, its presence seems to be related to the research subjects' clinical condition as, due to their treatment and the weakness itself caused by the disease, CRD patients suffer countless losses related to different daily activities. These patients usually report on the presence of physical limitations, provoked by fatigue and constant pain, as an impediment to perform some tasks ${ }^{(1)}$. Therefore, the clinical indicator is incapable of expressing creativity is thought to be another particularity of the disease instead of a defining characteristic of the nursing diagnosis impaired spirituality.

Among the investigated defining characteristics, 11 were considered secondary for the diagnosis under analysis; of these, the defining characteristic expresses lack of serenity was present in $75.8 \%$ of the sample of CRD patients with impaired spirituality. In a content validation study ${ }^{(15)}$, anxiety was also identified as a major characteristic (score $\geq 0.80$ ) of the nursing diagnosis spiritual anguish.

The characteristic expresses lack of meaning/ purpose in life, which showed to be a secondary characteristic in this research, has been identified in literature as one of the important indicators of this nursing diagnosis in other validation studies ${ }^{(3,16)}$.

The defining characteristic feeling of grief was not included in NANDA's list of defining characteristics ${ }^{(6)}$ for the nursing diagnosis under analysis, although it had been validated in other studies ${ }^{(16-17)}$. In this research, $51.5 \%$ of the sample affirmed that they presented feeling of grief.

The characteristic feeling of temporality was not included in the list of defining characteristics proposed by NANDA ${ }^{(6)}$ either, but resulted from a previous content validation study for this diagnosis(5). In the present research, it was found in $70 \%$ of the research subjects. This aspect reinforced that all defining characteristics identified in earlier phases should be maintained in clinical validation. In view of these data, clinical validation studies of defining characteristics for a given diagnosis should maintain the indicators identified in earlier phases, independently of the scores obtained. This permits verifying agreement or not between different validation methods, an aspect that has already been mentioned in Brazilian research ${ }^{(18)}$.

Literature $^{(7)}$ suggests that defining characteristics with a score $\leq 0.50$ should not be considered validated. Considering these aspects, the defining characteristics expresses lack of love, expresses despair, does not 
take interest in nature, presents disorder or concern with the system of beliefs, expresses anger with God and is incapable of experiencing transcendence deserve further research, as they were little observed in the study population.

It is important for nurses to pay attention to the signs of impaired spirituality manifested by patients with chronic illnesses, so as to clarify information on how they perceive their situation and the meanings embedded in their experience, as well as to assess the role of spirituality aspects in these people's clinical conditions. Identifying the patients' conditions broadens nurses' ability to contribute to care, through greater efficacy and achievements of the established goals ${ }^{(18)}$. This kind of validation studies ${ }^{(19)}$ have offered important contributions to clinical practice, offering greater precision in the identification of nursing diagnoses.

\section{Conclusion}

The prevalence of the nursing diagnosis impaired spirituality in CRD patients undergoing HD was $27.5 \%$. Direct questions asked to patients about the presence of the diagnosis produced results similar to the nurses' assessment, who used a dichotomous questionnaire with the defining characteristics under analysis (Kappa: 0.92). Thus, the probability is highlighted of asking patients directly about the presence or not of nursing diagnoses that involve cognitive responses, provided that the phenomenon under analysis is defined.

Fifteen defining characteristics were validated in the clinical context, four of which were classified as primary and eleven as secondary characteristics of the nursing diagnosis impaired spirituality. Only six defining characteristics were considered of little relevance for the diagnosis under analysis in the study sample and, therefore, were not validated in this research.

According to the total score of 0.70 , based on the sum of all defining characteristics with frequency levels above $50 \%$, the diagnosis was considered validated in the clinical environment.

The application of a diagnosis in clinical practice demands nursing skills to investigate its defining characteristics; with regard to impaired spirituality, however, these are extremely subjective and personal manifestations. Hence, this study is limited by the fact that only conceptual definitions were established.

Further research on this nursing diagnosis in other populations is needed, using larger samples with a view to the generalization of results, as investing in research with clinical evidence will permit validating discoveries in the spiritual area and will consequently expand the link between health and spirituality.

\section{References}

1. Dyniewicz AM, Zanela E, Kobus LSG. Narrativa de uma paciente com insuficiência renal crônica: a história oral como estratégia de pesquisa. Rev Eletrônica Enferm [seriado na Internet] 2004 maio-agosto [Acesso em 12 dezembro 2006]; 6(2):199-212. Disponível em: http://www.fen.ufg.br/revista/ revista6_2/narrativa.html

2. Grant E, Murray.SA, Kendall M, Boyd K, Tilley S, Ryan D. Spiritual issues and needs: perspectives from patients with advanced cancer and nonmalignant disease. A qualitative study. Palliat Support Care. 2004; 2(4):371-8.

3. Twibell RS, Wieseke AW, Marine M, Schoger J. Spiritual and coping needs of critically ill patients: validation of nursing diagnoses. Dimens Crit Care Nurs. 1996; 15(5):245-53.

4. Chaves ECL, Carvalho EC, Goyatá SL, Galvão CM. Spiritual distress: integrative review of literature. Online Braz J Nurs. [serial on the Internet]. 2008 July 15; [Cited 2009 June 1]; 7(2):[about 09 p.]. Available from: http://www.uff.br/ objnursing/index.php/nursing/article/view/1551

5. Chaves ECL, Carvalho EC, Hass VJ. Validação do diagnóstico de enfermagem Angústia Espiritual: análise por especialista. Acta Paul Enferm. 2009. (prelo)

6. North American nursing Diagnosis Association. Diagnósticos de Enfermagem da NANDA: definições e Classificação 20072008. Porto Alegre: Artmed; 2008.
7. Fehring RJ. Methods to validate nursing diagnosis. Heart Lung, 1987; 16(6):625-9.

8. Miner-Williams D. Putting a puzzle together: making spirituality meaningful for nursing using an evolving theoretical framework. J Clin Nurs. 2006; 15(7):811-21.

9. Villagomeza LR. Spiritual distress in adult cancer patients: toward conceptual clarity. Holistic Nurs Pract. 2005; 19(6):285-94.

10. Rosner B. Fundamentals of Biostatistics. 6. ed. Belmont: Thomson Higher Education; 2006.

11. Lima T, Cruz I. Patient in peritoneal dialysis and the risk of infection: evidenced based nursing practice. J Specialized Nurs Care. [serial on the Internet]. 2008 July 7; [Cited 2009 June 1]; 1(1):[about 09 p.]. Available from: http://www.uff.br/jsncare/ index.php/jsncare/article/view/1655

12. Souza EF, Martino MMF, Lopes MHBM. Diagnósticos de enfermagem em pacientes com tratamento hemodialítico utilizando o modelo teórico de Imogene King. Rev Esc Enferm USP. 2007; 41(4):629-35.

13. Carpenito-Moyet LJ. Compreensão do processo de Enfermagem. Porto Alegre: Artmed; 2007.

14. Williams AL. Perspectives on spirituality at the end of life: $A$ meta-summary. Palliat Support Care. 2006; 4(4):407-17.

15. McHolm FA. A Nursing diagnosis validation study: defining characteristics of spiritual distress. In: Carroll-Johnson RM, 
editors. Classification of nursing diagnoses: proceedings of the ninth conference of North American Nursing Diagnosis Association. Philadelphia: Lippincott; 1991. p. 112-9.

16. Hensley LD. Spiritual distress: a validation study. In: Carroll-Johnson RM, Paquette M, editors. Classification of nursing diagnoses: proceedings of the tenth conference of North American Nursing Diagnoses Association. Philadelphia: Lippincott; 1992. p. 200-2.

17. Pehler SR. Children's spiritual response: validation of the nursing diagnosis spiritual distress. Nurs Diagn. 1997; 8(2):55- 67.

18. Cruz Diná de Almeida Lopes Monteiro da, Pimenta Cibele Andrucioli de Mattos, Pedrosa Maria Fernanda Vita, Lima
Antônio Fernandes da Costa, Gaidzinski Raquel Rapone. Nurses' perception of power regarding their clinical role. Rev. LatinoAm. Enfermagem. [serial on the Internet]. 2009 Apr [cited 2009 October 19]; 17(2): 234-9. Available from: http:// www.scielo.br/scielo.php?script=sci_arttext\&pid =S0104$11692009000200015 \&$ Ing=en. doi: 10.1590/S0104-116920090 00200015.

19. Melo AS, Carvalho EC, Haas VJ. Defining characteristics, validated by specialists and manifested by patients: a study of the sexual dysfunction and ineffective sexuality pattern diagnoses. Rev. Latino-Am. Enfermagem. 2008; $16(6): 951-8$. 